\title{
Seeking a Prairie Farm: A Scotsman's Search through Missouri to Iowa in 1865
}

\author{
EDITED BY BRIAN P. BIRCH
}

During the middle decades of the nineteenth century, improved river and rail transport made midwestern prairies more accessible and fostered, in part, a growing appreciation of their advantages for farm settlement. Westward-moving farmers did not see settling the prairie simply in terms of its direct benefits over clearing wooded land; the spreading interior communications network of riverboats and railroads also made it possible for would-be settlers to search more extensively for suitable farms and turned the attention of many to the prairies' advantages. ${ }^{1}$ As more travelers in the increasingly settled Midwest passed back conflicting information by letter, pamphlet, and word-of-mouth, many prospective settlers felt compelled to inspect as many areas as possible before deciding where to buy a farm. In effect, these later settlers who were "filling in" the farm settlement pattern behind the frontier were gaining this

${ }^{1}$ Allan G. Bogue cites a number of additional factors influencing the flow of settlement into midwestern prairies: "Transportation routes and facilities, potential markets, the quality of the land, real or imagined, location in relation to older settlements, and the state of the settling-in process there-all had important effects. . . " "From Prairie to Corn Belt (Chicago: University of Chicago Press, 1963), 12. See also Douglas R. McManis, The Initial Evaluation and Utilization of the Illinois Prairies, 1815-1840, University of Chicago, 
greater mobility to search for land instead of the endless choices of farmsites the earlier settlers had enjoyed. The first pioneers, moving ahead of the transport system, had few opportunities to search extensively for suitable land before deciding where to settle and farm. Instead they could, and often did, pack up and move on after a few seasons as settlement and land prices increased around them. In this way they extended their search for suitable farmland over a period of years as they moved along with the frontier. Those that came later to complete the settlement did not have so much freedom to move so that, to them, the decision on where to settle-in woodland, at the prairie edge, or on the prairie-was to be more crucial. Some joined group settlements or other schemes to help relieve them of the difficult choice. ${ }^{2}$ Others took advantage of the railroads, riverboats, and other means to inspect a wider range of available lands before deciding for themselves.

Little is known of these individual searches, but the diary of George Rae, held in Iowa State University Library's Special Collections and reproduced here, provides an example of the process of looking for suitable land ${ }^{3}$ His journal covers a ninemonth period in 1865 when he migrated, at the age of twentyfive, from Maine to Crawford County, Iowa. Rae originally headed for northern Missouri where he wished "to inspect the boundless prairie. "4 It is clear from his journal, however, that because of the high prices asked for Missouri farms, he decided to head north into southwestern Iowa where land prices were lower. The last seven months of the diary show that George Rae settled for a time in Harrison County where he was employed in a sawmill and where he purchased his first quarter-section of school land on the Missouri River bottoms. Towards the journal's close, he was hired as schoolteacher in Crawford County

Department of Geography Research Paper \#94 (Chicago, 1964); and Terry G. Jordan, "Between the Forest and the Prairie," Agricultural History 38 (1964): 205-216.

${ }^{2}$ In the case of British group settlements in Iowa see, especially, J. Van der Zee, The British in Iowa (Iowa City: State Historical Society, 1922).

${ }^{3}$ The Rae Family Papers, Special Collections, Iowa State University Library, Ames, Iowa (hereafter cited as RFP).

${ }^{4}$ Newspaper clipping (obituary of George Rae, n.d.), RFP. 
where he shortly after bought the land he was to farm for thirty-six years until his retirement in 1904.

Two points about George Rae's background help to interpret the tour recorded in his diary and his eventual decision to settle and farm in lowa. First, as a young, urban, working-class emigrant from Scotland to New England there is ample evidence to show that he was spurred on by a desire to better his circumstances. Second, this implied for him, as for many British emigrants to America at this time, the ownership of either farmland or a small business enterprise. Rae was born in 1840, the third of ten children, to a family in Kingskettle, a small Scottish town on the edge of the Fifeshire coalfield. He was working as a warehouseman in a linen textile mill by the age of fifteen. With his formal schooling as limited as his family's finances, selfimprovement became a major goal. His secretaryship of the Kingskettle Young Men's Mutual Improvement Association, one of many such betterment clubs which had sprung up in industrial Britain, points to this, as do his strong attachment to Christianity in general (and working-class Methodism in particular) and his decision to emigrate to America at the age of twenty-one. When he crossed the Atlantic in 1861 he took with him a testimonial from his former employer who spoke of his "strictly steady and sober habits . . . careful in the performance of his duties." ${ }^{5}$

After four years in the Saco-Biddeford area of Maine where he did millwork, he decided to move west in search of other work in order to save and buy a farm, or possibly a small mill. It is not possible, however, to ascertain from the available records why he traveled to the Midwest prairies to inspect land. Certainly from the outset of his trip west, and before he had even gone beyond New Jersey, he was noting contrasts between the flat, swampy wooded lands of the coast and the more favored prospects of the elevated, grassy interior lands. While, for example, he was disparaging of farmland bordering Lake Erie where a "considerable part of the way is woody and as much as half that is cleared is full of stumps," he had earlier noted of interior New Jersey that the "country improved as we

${ }^{5}$ Alexander Lawson, "Testimonial to George Rae," 25 April 1865, RFP. 
got among more elevated lands where the grass is quite green and buildings good." On first seeing the prairie in northern Illinois he "was very favourably impressed." Rolling prairieedge land without a dense cover of trees clearly attracted Rae as it did many British settlers, the more lyrical of whom likened it to the best English landscapes and gentlemen's parks. ${ }^{7}$ Similar impressions of the prairie had appeared in emigrant guides which Rae may have seen. ${ }^{8}$

Perhaps in linking his hopes of betterment to ownership of prairieland George Rae was behaving in a way typical of many British emigrants, but other aspects of his personality also seemed to influence the progress of his search for land. In particular one can note his versatility, first, in deciding almost on a daily basis the route of his trek to follow up the many pieces of information he received about farms and mills for sale; and, second, in adapting to a range of jobs from millhand to schoolteacher when he first arrived in Iowa. His gregarious nature also made it possible for him to pick up plentiful advice, acquaintances, and traveling companions as his tour progressed. Of forty-three nights he spent on his journey to Iowa only sixteen were spent on trains, boats, or in boarding accommodations; twenty-seven were spent in the homes of acquaintances made before or during his tour.

For the sake of brevity the first five days of Rae's journal recording his journey from Maine to Chicago are omitted, as well as a number of later diary entries mainly concerned with his correspondence, the weather, and his observance of the Sabbath. His first destination beyond Chicago was the farming community of Morrison in the prairie of northwest Illinois where he had arranged to stay with the Wallace family, acquaintances from New England.

'Journal of George Rae, 12 April 1865, 14 April 1865, RFP.

${ }^{7}$ Brian P. Birch, "British Evaluations of the Forest Openings and Prairie Edges of the North-Central States, 1800-1850," The Frontier: Comparative Studies, ed. William W. Savage, Jr. and Stephen I. Thompson (Norman: University of Oklahoma Press, 1979), 2:167-192.

${ }^{8}$ See, for example, John Newhall, A Glimpse of Iowa in 1846 (Burlington, IA: W. D. Skillman, 1847), 18. 


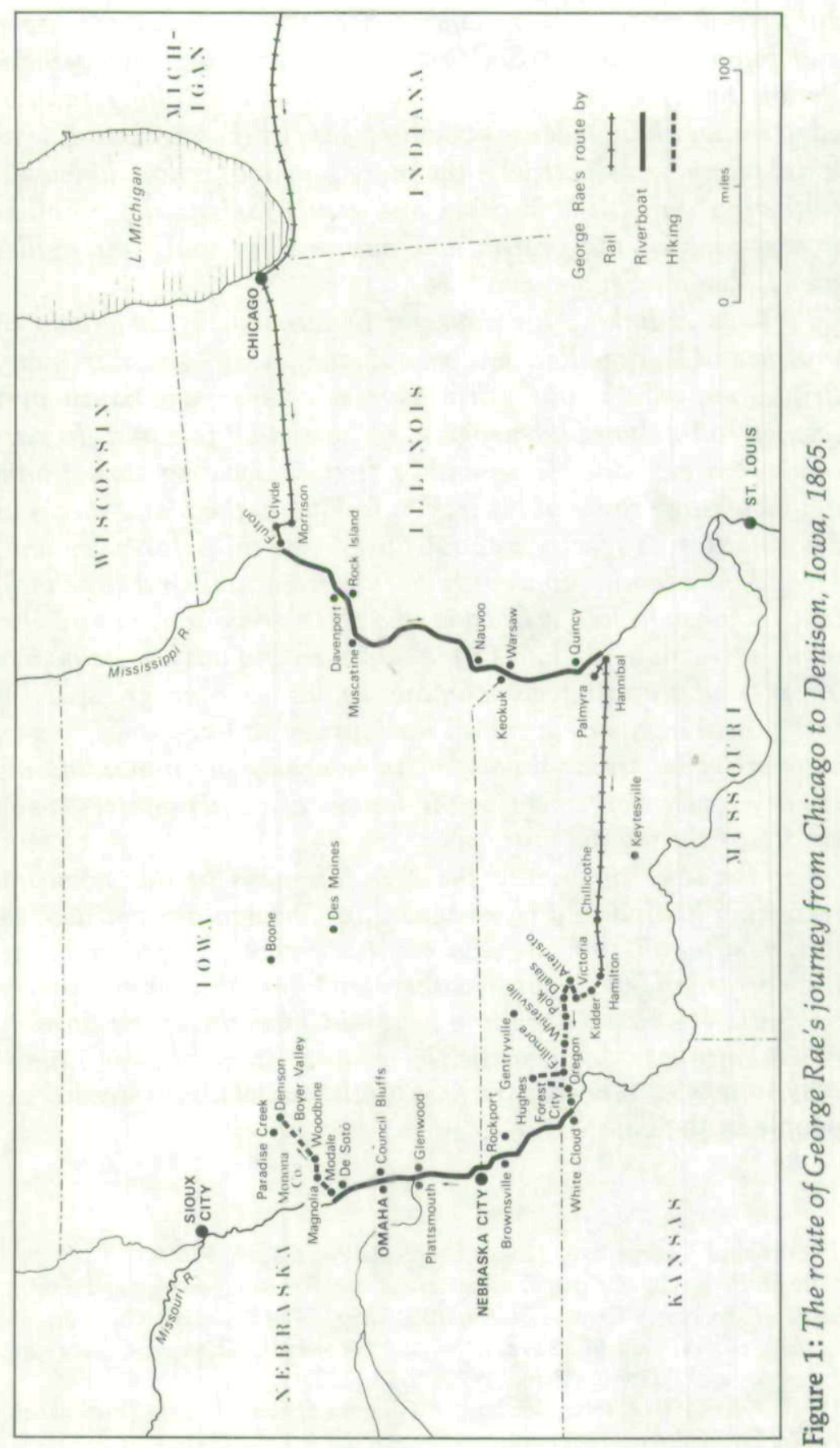




\section{JOURNAL:}

15th April, 1865. At 8:15 a.m. left Chicago for Morrison. Was very favourably impressed with the prairie through the State of Illinois as it was so much better-like in appearance than the other states through which we passed. Found Mr. Wallace, son Robert, brother Adams and wife at the depot. Between Morrison and Clyde the country is very broken and the roads were bad indeed. Susan Wallace, daughter of Adams, acted as housekeeper when we arrived there. We found the house a very comfortable one-one storey and a half high. Partook of a hearty meal which was indeed grateful after a rough week on the [rail] cars. ... .

17th. Mr. Wallace's barn consists of a stable on the basement, corn, wheat, oats and hay bins above with places for putting past spare machinery or implements. Harrowed two hours this forenoon after oats and tried the sowing of some of them. Afternoon went down to Morrison and there mailed two letters. . . .

18th. Clyde, Illinois. Tried my hand at farming again by harrowing and sowing. Found it hard work but gives me a good appetite which is good. This afternoon Robert and I called on Adams and family and there got tea and afterwards we called on Mr. Snyder's family which consisted of Mrs. Snyder and three daughters along with hired man and a little boy. The daughters were highly accomplished in music. They gave us some tunes on both melodeon and piano accompanying them with their voices. Society here are very free and easy to mix with and as they do not have the airs of wealthy people in the East.

19th. Rainstorm with heavy thunder and lightening [sic]. Cleared up in the afternoon when Robert and I went to Morrison in the buggy waggon. The roads were full of water in the ruts which made it nasty. At 12 o'clock services were held in the different churches over the death and funeral of President Lincoln.

21st. This forenoon helped to put up a rail fence around one of the fields. After dinner harrowed awhile and then between 
4 and 6 o'clock plowed which I found to be very agreeable and easy. The land is soft and easy to work either by spade, plow or harrow. . . .

1st May. Left William Wallace's this morning at 7 in the team with Robert. . . . Got to Fulton in good time. Enquired at the Boat Office for the boat down the river and was informed that one would not pass until tomorrow. Put up at the Robinson House for the night. Fulton seems to be rather a dull sort of a place.

2nd. Had a good night's rest in the hotel and a good breakfast in the morning after 7 o'clock. Spent an hour or two around the hotel and then called at the boat office where I made the acquaintance of the clerk there who was the son of a Scotsman who settled in Virginia and contracted to build the Lynchburg and Richmond Canal. He was a muse. Visited the upper part of the city and through the kindness of Prof. Stowe was shown through the building containing the school in which were five female teachers and Prof. Stowe and in all three or four hundred pupils. They were all very open and sincere, like in their expressions of happiness in seeing me. Stopped around the steamboat office all afternoon until the boat came. After getting on board took a good supper. . . .

3rd. Rock Island, Davenport. At 5 o'clock this morning on getting out of bed found we had arrived at the above places. Went through parts of both places as the boat stopped to load at both places. They were filled with large brick buildings, closely built together, streets wide and business apparently good. Railway connects on both sides by means of a bridge. At Rock Island the boat coaled and took on as freight, grain, flour, agricultural implements etc. At Davenport the freight was mostly grain all in bags. . . . Finally we managed to get away from this place at 12 o'clock noon. The scenery along the river is quite pretty. The river is high so that most all the islands and banks are overflowed so that the roots of all the trees, which are abundant, are covered up.

Muscatine, Iowa, lays on the edge of a bluff, is a place of considerable importance and might be half as large as Davenport. Went up town as far as the principal street and then 


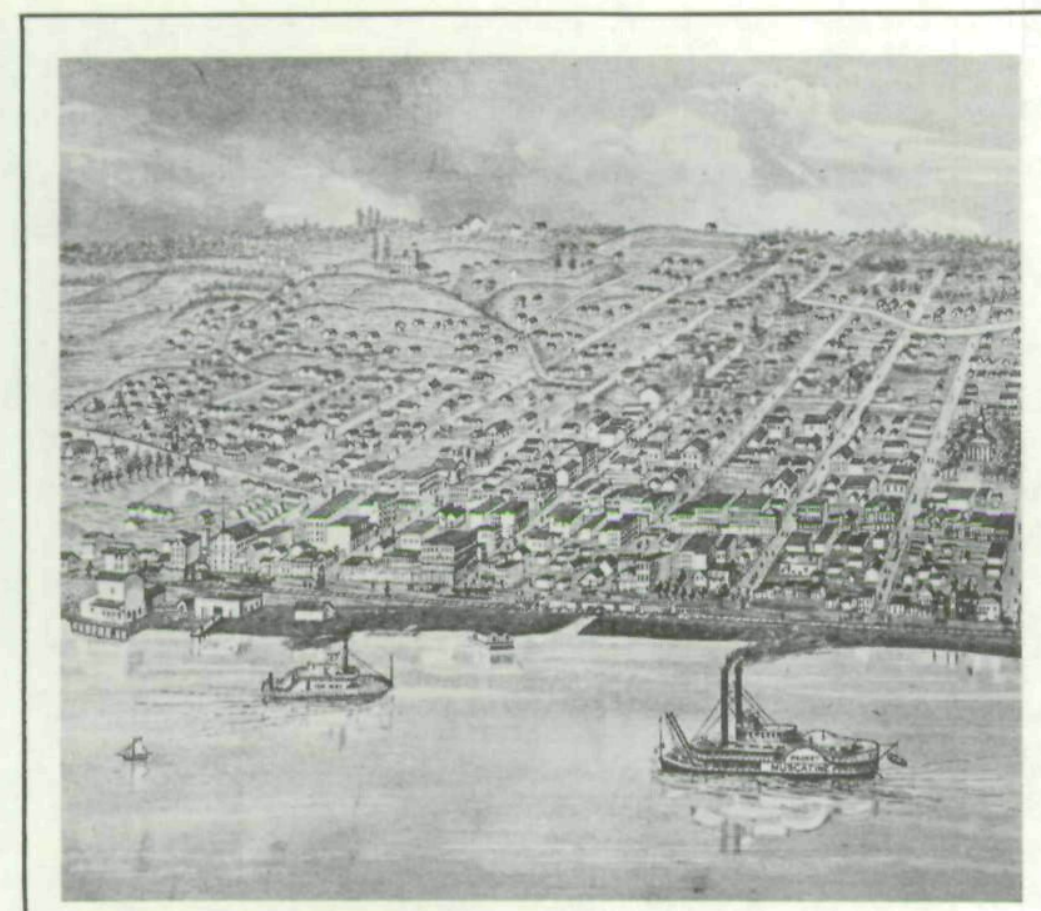

As he traveled down the Mississippi on a steamboat, George Rae would have seen Muscatine, Iowa much as it appears in this etching from the 1875 Andreas Atlas.

returned to the boat once more. Took on a large lot of grain and potatoes. Above Rock Island are large barrack accommodations for rebel prisoners. They are built in rows, one storey high, white painted and look quite comfortable. When we passed them in the morning, lights were shining through as though they were building their fires. They were surrounded by a high close fence outside of which were placed sentries who were pacing to and fro on their weary beat. On the opposite side above Davenport were accommodations for Federal soldiers, built on the top of a bluff.

This afternoon the wind has got to be quite boisterous which makes it disagreeable to be exposed on deck. Have been well supplied with meals today. Plenty of beef, potatoes, 
brown bread, flour bread, pudding, vegetables, cake, pies, etc. making it quite an easy matter to be on shipboard a couple of days. The company are sociable and chatty.... .

4th. This morning at $1 / 2$ past 5 alongside of Nauvoo, 80 miles from Hannibal. Got to the first town in Missouri opposite Warsaw in Illinois about 9 o'clock this a.m. For 12 miles above Keokuk are what are called the Mississippi rapids. On both sides the river is bounded by high rocky bluffs which rise abruptly from the water's edge. On the banks the trees are clothed in green, and the fruit trees are in blossom. William A. Leonard, Keytesville, Chariton Co., Missouri. Received the above address from the gentleman himself who was on board the boat going to his home. He has one hundred acres of land, fifty in timber, the remainder under cultivation. There is on it a good brick dwelling house, large tobacco warehouses etc., etc. which he offers for the sum of $\$ 2,500$ or $\$ 25$ an acre. Got dinner when the boat arrived at Quincy, Illinois. On the edge of the wharf is a very large depot of the railroad from Chicago. The city is very large. On the Missouri side opposite is only accommodations for the cars to Palmyra on the Hannibal and St. Joseph Railroad. Have enjoyed my trip down the river very well. ... .

Palmyra, Missouri. Came on here from Hannibal with the 3 o'clock train. Found the place very dull. Could not divine the reason until I found that all the stores were closed on account of the funeral of the President at Springfield. There are a great abundance of fruit trees in this vicinity all of which were in full blossom, the lilac was also in blossom. Returned to Hannibal with the freight train at 7 in the evening, and put up at a Mrs. Wilson's boarding house where I got a good breakfast in the morning, bed for 25 cents, breakfast 40 cents.

5th. After breakfast called at the office of the railroad ... . then called on Rev. E. P. Turner and got valuable information from him and the names of the counties in Missouri. He advised me to go as far as Kidder and then stop over Sunday. ... Had a goodly number of passengers on board, real social, good-hearted fellows on board. A good many of them came from St. Louis. At Palmyra found a great many 
more passengers who had come from Quincy. All the country through here was in full blossom and a delicious fragrance filled the air and was wafted through the windows of the cars. Got acquainted with a Mr. Slade and one or two others from the East. . . .

6th. Kidder, Missouri. Arrived here this morning at 1 o'clock. Put up at the Kidder House. . . . Saw Mr. Allen, [the land] agent, who informed me wild lands were held at about 12 to 15 dollars an acre. He sent me to a Mr. I. Curtis who has an 80 acre lot to sell. Found on going there that he held it at 15 dollars an acre. 16 acres were fenced in, a small house ... no cistern or cellar or other outbuildings. About half of the place was prairie, the other a poor specimen of timber, a young orchard was there. He agreed to give it [to] me on his present offer a month from now if unsold. Walked along the cars' track as far as Hamilton. There went into a combination store, took a seat and engaged in conversation. Found out by a Mr. Claypool that he held a farm for sale $2 \frac{1}{2} 2$ miles from the village. Went in that direction and called at the place. Found on it good dwelling house accommodation consisting of two furnished rooms, size 16 feet by 16 feet and another of the same size all finished except windows, doors, floor and plaster. He had a nice orchard on it, four log cabins, 53 acres fenced in with a good rail fence. Of good prairie land he had 120 acres and 20 in timber a mile distant. He is willing to let it go for $\$ 2000$.

[Locations of several farms and a mill for sale are also listed.]

8th. ... Arrived at Victoria in the evening when I went to bed in a house attic. Was very tired and soon fell asleep but awake an hour after, all swelled up and in a high fever, and tossed around all night and at daylight found it was all caused by bed bugs. It was the most restless night ever I spent in my life.

10th. Jefferson Township. Intensely cold. Slept at $\mathrm{Mr}$. Morrison's who is an Advent seventh-day preacher. No charge for bed and breakfast. Saw at noon five teams with three yoke of cattle each away to Idaho. They were rebels 
from the vicinity of Chilicothe. Besides the cattle teams they had one with two horses containing provisions. Had dinner at Mr. Morrison Jn. . . . he then showed us around some farm of 80 acres at $\$ 10$ an acre; small log cabin; some brushwood, Township 59, Range 29. Some excellent railway lands here in beautiful locations.

11th. Alteristo, Daviess Co. . . . At this village is a steam mill for grist and saw-mill which is a little out of repair but could be got cheap and would pay well. There is a good circular saw, engine of two boilers. The next house contains two sets of burr stones for corn and wheat. Price thought to be all got for about $\$ 1000$. There is a good two storey house ... lot could be got for $\$ 500$ or $\$ 600$. . . .

[The locations of several more farms including comments on their prairie and timber are listed at this point. Rae and another easterner, S. A. Slade, had become acquainted a week before on the rail journey across Missouri and became traveling companions for the next twenty-two days.]

12th. Dallas, De Kalb Co., Missouri. We are now in the above place. Mr. Slade and I are putting it through in a pleasant style. We find all loyal men are social and friendly to the utmost extent. The women are healthy looking through the county.... The men are busy putting in their corn in the most slovenly way not even plowing the soil more than enough to drop the corn in. The county is well timbered on the streams with good upland prairie between.

Polk Township, noon. Section 24, Township 60, Range 32. We stopped to dinner on the edge of a creek bordered with a heavy growth of timber after crossing a large, open, good prairie. Good farms can be sold here at about $\$ 10$ or $\$ 12$ an acre. Prairie on the timber from $\$ 3$ to $\$ 5$ an acre. . . . Met a man here from Gentryvile [sic] who says there are plenty of farms for sale in his vicinity.

13th. We slept last night at a woman's house where her husband had gone to the war. Township 61, Range 33, Wisconsin settlement, farms over $\$ 10$ an acre, the prairie held at $\$ 5$ to $\$ 8$ per acre. Got breakfast at a Mr. Sherman's who is Dutch. He has a farm of 400 acres 80 of which is timber. He got it a year 
ago for $\$ 8$ an acre and now asks $\$ 20$ an acre for it. Passed through Whitesville at about 11 o'clock. Found it quite a village but it had very little appearance of enterprise about it indeed. Enquired about farms all afternoon. Found them from $\$ 20$ to $\$ 25$ per acre.

[Details of three farms and a woolen mill, all for sale, are given at this point in the journal as well as the names of several more acquaintances made on the journey.]

15th. This morning took a stroll to Township 62, Range 37, Hughes, Nodaway Co. where we got our dinner. It is within two miles of the Nodaway river on which are very pretty bottom lands where are an immense herd of mules looked after by a herdsman on a mule's back. Lands are high-priced ranging from $\$ 15$ to $\$ 25$ an acre. Met a Georgian refugee in this vicinity from the neighbourhood of Chattanooga. Got supper .... in an Eastern style which was very acceptable after so many sights we have seen in our wanderings.

16th. Put up last night at [the home of] . . . a good Methodist brother and his wife, a New York Yankee, and a thorough go-ahead. We had an excellent bed and room.... This place is for sale. There is good houses on it.

17th. ... Started for Oregon, [Missouri,] crossed the Nodaway [River] at Duncan Mills, on the dam. Found the prairie broken up very abruptly and not possessing the gradual swell of the more eastern county. Tried at a great many places to get some dinner but was unsuccessful until we got as far as a Mr. Bragg's. We had some for which we paid as much as 40 cents. After crossing the prairie and having got within three miles of Oregon called at a Mr. Young's to get a drink and a rest and was there informed that a lot of guerrillas were in the grove nearby and that there was great excitement in town last night over the affair. Lands here are from $\$ 20$ to $\$ 30$ an acre. On getting into Oregon called on Mr. Stephen Blanchard and was invited by him to remain all night. . . .

18th. Oregon, Holt Co., Missouri. After an hour's agreeable conversation with $\mathrm{Mr}$. Blanchard went out to look at the city. There were some good buildings, court house, school, 
churches with good orchards. Called on a Mr. Gaymaker, a German who has an excellent grapery with sixteen varieties in it. He has a nice assortment of other fruit also. . . .

19th. Forest City, Missouri. Came to this place yesterday evening and found we were $1 / 2$ an hour late for the boat up the river as we resolved to go up to Monola [Monona] Co., Iowa. Our reasons are that land is for sale in that county about $\$ 11 / 2$ an acre; it is in a more enlightened state and away from the dreadful ravages of this war. Put up for the night at the Planters' House where we had a good bed. This morning started without any breakfast and walked up the river 6 miles distant to a place opposite White Cloud, Kansas, to which place we crossed in the ferry boat. .... Mr. Slade and I walked out in the county some ways to a farmer's house nearby when we heard the whistle of the boat and returned to find we were $1 / 2$ an hour too late. We felt cheap enough to think that we lost it by the same delay yesterday and again today.

The people of Kansas have a marked contrast in their appearance from those in Missouri. They are dressed in much better style and also are more intelligent and energetic in their business affairs. Put up at the hotel in town tonight and paid the fare before going to bed so as to run any time if occasion [demanded].

20th. White Cloud, Kansas. This morning on getting out of bed at $1 / 2$ past 5 saw the boat coming up the river. We got on board at 6 o'clock and bade farewell to Kansas on the "Siouz City" [sic]. Got breakfast at 7 o'clock in similar style as on the Mississippi boats after getting our tickets to Omaha which is as far as the boat runs to which we got for $\$ 10$. The progress of the boat is very slow owing to the shallowness of the river in many places, snags etc. The wind blows so strong too that the current is not noticed as it would be were the weather calm. The Missouri river resembles a mud puddle. Its banks in most places are composed of a fine sediment left by the stream at different times. Owing to the rise and fall of the river in the spring, the channel changes frequently so that it is difficult to navigate on it easily or speedily. After supper the wind fell and it got to be quite cool and agreeable on deck. . . . 


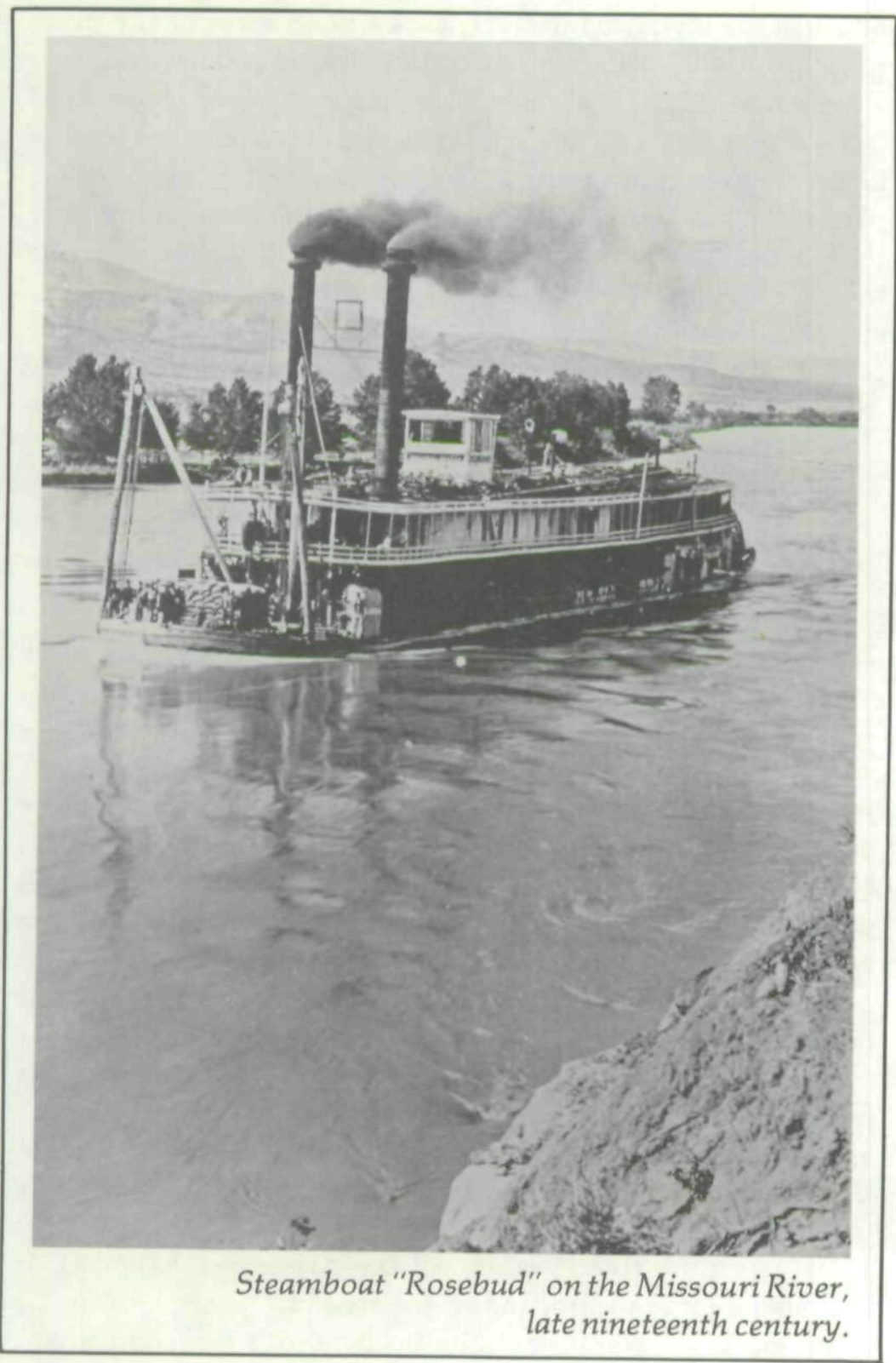

21st. Brownsville, Nebraska. This morning clear and pleasant. Passed the country above Rockport where were some beautiful bottom lands but no timber on it. There was timber on the 
bluffs in the distance however. Got a good view of the place from the pilot house with the country around and beyond. . . .

Nebraska City, Nebraska Territory. Arrived here at 3 o'clock p.m. went up the main street and found it a growing place, a great many stores and saloons and other business places. This is a great starting point for emigrants going over the plains. Wagons in great numbers were scattered over the town, agricultural implements, gold mining machinery etc., etc. New dwelling houses were also going up fast. It is a point for the rebel runaways from Missouri to centre in so that they may diverge out the country or go over to the Pacific territories. The boat is unloading a large amount of freight here. Being Sunday the people are mostly idle and down about the river. It is not a pleasant-like Sabbath at all and makes one long for the quiet country home in peace and serenity to dwell.

22nd. Glenwood, [Iowa]. This morning is cool and nice to be on board the boat. At 9 a.m. landed at Glenwood, Iowa. Talked awhile with a farmer boy about the country in the vicinity. It was all settled, he said.

Plattsmouth, Nebraska Territory. This is a thriving place but could not get to it as the landing was too far from the city. Here was a college in course of erection of brick. From this point on the Iowa side a rim of bluffs run up for miles and are very pretty. In some points they are close on the river, at others a wide stretch of bottoms extend from the river to their base. The Platte river empties into the Missouri.

Council Bluffs, Iowa, landing. About two miles below this point a dead man's naked body floated past the boat but attracted no more attention than a few passing remarks from the passengers. The river takes a round-about turn from here to Omaha, making an air line distance overland of 5 miles to 12 miles on the river. Nearly all the passengers have left us and also a large proportion of the freight.

Omaha City, Nebraska. Got up here at 6 p.m. On board was a lot of railroad iron, the first that was ever brought so far up this river. The railroad westward is commenced at this point and 100 miles are to be built this summer. One million bricks are contracted for to build a depot at this city. On 
going ashore we found the city laid out for a large place and the citizens indulging the hope that the place would be the great city of the west. Lots for building were held as high in the business part of the town as $\$ 5000$. It is on a beautiful site, viz. an upper bottom and has a high bluff for its background with the State House on the summit. There were commodious hotel accommodation etc.

The "Hattie May" is a boat going up as far as Fort Benton. On it we got about 9 p.m. Mr. Slade, on ascertaining the fare to be $\$ 7$ resolved to go home from Council Bluffs which were 4 miles east and from which stages run to connect with the cars at Des Moines.

There are numbers of Indians up and down the banks of the river here of various tribes, dressed in all varieties of style. Some are nearly in a state of nudity.

23rd. Left Omaha at 6 a.m. Got up 35 miles by $1 / 2$ past 12 noon. The river is very winding up here. Only fev signs of settlement to be seen all the way up. De Soto is a pretty little town situated on the edge of a bluff some little distance from the river. . . Stopped at a wood yard about opposite the town of Magnolia, to wood up and stop all night. The steward made a purchase of sweet and buttermilk for the use of the boat.

24th. At $1 / 2$ past 6 a.m. came up alongside of the "E.O. Stanard" which had got a hole knocked in her bottom by a snag a week ago Sunday. She had been raised and put to the bank and repaired and is to be sent down the river again today. Some of her passengers and freight were put on the "Hattie May" for Fort Benton. Lots of Indians were on the banks here, mostly "Winebagoes" [sic]. At this place made the acquaintance of a Mr. Dennis who owns a sawmill two miles from where the boat stopped. . . . Agreed to work awhile for $\mathrm{Mr}$. Dennis at various kinds of work.

25th. Put me to fixing up some flour and corn meal, then kindle fires among stumps and brush in his garden and also chopping firewood out of old lumber laying around his yard.

[Once settled near Magnolia and employed in Mr. Dennis' woodyard and sawmill, Rae took the opportunity to look at 
other means of earning money with which to buy land. Freedom from constant traveling also allowed him to spend his Sundays much as he had in Scotland and Maine.]

26th. Took a journey to Magnolia with Mr. Dennis. It is the county seat. . . . Asked a Mr. Clarke about a woolen factory now in the course of erection. He expects it to be ready to run in August. His foreman is away now after machinery. . . .

18th June. . . . wrote to Mrs. Wallace on yesterday's [event]. A company of 12 or 14 men called on Mr. Dennis at his mill and requested him to discharge the Indians which he has been employing of late and on his refusal they threatened to kill the Indians themselves if they did not quit the country. Notice had been given to all the Indians on the bottom [land] in this county to leave and they had promised to do so in three days. The men were armed with rifles, revolvers and bowie knives and used mean menaces to Dennis and the Indians. . . .

19th. In company of two of Mr. Dort's men [of the sawmill] I visited the Post Office where a Methodist preacher was giving a sermon. Quite a number were present. . . . [I am going] to work now in Dennis' sawmill. . . . It is hard work but I like it pretty well as it is in the shade and being open all around there generally is a breeze ablowing.

22nd. This morning Mr. Dort's men left us to raft a lot of timber down to Omaha. . . .

2nd July. Sabbath. During the past week have been, except on Monday, engaged in the saw-mill on railroad timber. . . .

6th August. At Sabbath School this morning. Newberry [the] teacher in the absence of the Assistant Superintendent. I did that part. . . .

9th. An astronomical lecture and show was given in Modale Schoolhouse tonight. The house was filled and pleased with the sight. . . .

20th. Sabbath. Went to what is known as Buck's schoolhouse where Sabbath School was held.... Got a letter from Henry Davis asking about the West and wishing to come out. ... 
[After working for Mr. Dennis for three months Rae was able to purchase a quarter-section of bottom land near Magnolia although he continued with Dennis for another three months acquiring new skills in the mill.]

26th. Went to Magnolia today in company with $\mathrm{Mr}$. Dennis. ... At Magnolia an auction sale of school land took place. Bid for two eighties [eighty acres] in Section 16, Township 79, Range 44 at $\$ 3$ an acre. Terms one third down and the balance in ten years. Got home about 10 o'clock and suffered in the journey from mosquitoes. . . .

2nd September. This has been a very warm week. Four days have been [working] on the fence on the west side of the field. ... Mr. Stanwood and I nailed on the boards, and Indians mostly dug the post holes. Got a letter tonight from George Jordan of Michigan enquiring about the West where I am.

4th. ... Commenced with Indians to cut logs for railroad ties today. While in the timber got $\$ 2$ a day.

6th. Sick this morning and unable to work. Took the opportunity afforded by Mrs. Hester and sisters going to go up to Magnolia and settle business of land. Got it done by paying one-third of the amount down. . . .

10th. Sabbath. ... Meeting in Mr. Coles' grove where preached Mr. Pennington and Snyder. At the close four women and one man were baptised in Fish Lake. ... .

11th. ... Worked in the timber in the afternoon along with four Indians. Evening received $\$ 50$ from Mr. Dennis in part payment for work. . . .

24th. ... Worked last week one day chopping, two logging and three in the mill. ... .

29th. This morning had a surprise in a visit from G. V. Jordan from Michigan. He started to work for Dennis after dinner. Four days this week I have logged, today worked in the mill. ... .

2nd October. Had a job this forenoon cleaning out the furnace for to fill up the engine boiler as it had got choked up with mud. In the evening was sent to try and hire Ibel Day to 
come and saw for Dennis but could not as he had work enough at home and during winter he intended to run an engine in a grist mill over the river.

3rd. This morning was sent to try and hire Mr. Browning to saw for Mr. Dennis but could not. Offered to try my hand at sawing to learn it a little. ...

7th. During the week have sawed considerable and fired also to some extent. . . .

10th, 11th. Was waked up each of these mornings and ran the saw half the night. . . .

14th. Worked all day today making in all for the week seven days and three quarters. ...

22nd. During the week have run the engine [in] the mill daytimes and worked at the saw the latter half of the nights, all except Monday morning making eight and a half days. . . .

23rd. Today did not feel very well from the effect of boils and disordered stomach and took the day to myself. . . .

25th. Boat came up after [railroad] ties from Dennis. Put in three-quarter's day today. Tonight was not able to eat any supper.

29th. Have been very sick since Wednesday evening. Had a visit from Dr. Rice this afternoon. He pronounced my illness to be Dumb Ague. Left a number of powders to take and charged $\$ 9$ in all for his visit and advice with the medicine. . . .

2nd November. Went to work this morning but felt weak. Fired the engine all day.

[Rae's illness continued throughout the next month and probably influenced his decision to leave his job in the mill. He moved away from the river bottoms up into Crawford County where he became a school teacher and later bought more land.]

20th. . . . Took a walk through the timber and on as far as Thomas Whitcomb's where, after being half an hour there, had a chill and fever pretty bad again. Got home about 4 
o'clock feeling as tired as though I had walked 20 miles. At supper time took a little supper and afterwards a pill.

30th. Started for Dennison [sic], the county seat of Crawford County this morning. It is a scattering village; had a good courthouse and a high position where blows the winds of heaven. ... .

1st December. . . A A Mr. Strong of Paradise Creek tried to hire me to teach school in his district but did not feel at liberty to hire as I had promised Albert Wakefield to go in with him ateaming it over to the [rail] cars.

2nd. Heard last evening that the contract for hauling wagons from Boone to Council Bluffs had been let for over a month so I resolved to hire out as teacher. Contracted . . . to teach the school for 16 weeks of 5 days a week at $\$ 35$ a week. Mr. Butler [school district officer] agrees to board me for a dollar a week, cheap enough.

18th. Escaped ague today. Have been taking cherry and white ash barks for it. .... Sent a note to Mr. Butler craving indulgence of the School for this week as he has sent making enquiries for me.

19th. . . Contracted for 10 sheep at $\$ 4$ a head to be delivered next Saturday. ... .

25th. We went up with Mr. Butler to see the School Superintendent at Dennison. I was examined and got a certificate. . . .

28th. Have kept school for three days. ... .

The diary ends at this point apart from lists of travel expenses and other miscellaneous information, but other family papers make it clear that in addition to the 160 acres of school lands he had purchased on the Missouri bottoms in Harrison County in August 1865, George Rae also acquired several pieces of land further up the Boyer Valley in Crawford County during and after 1868. It was on this land that he established his farm which, with an associated cheese-making firm, formed the basis of his livelihood until he retired. As Figure 2 shows, his first land 

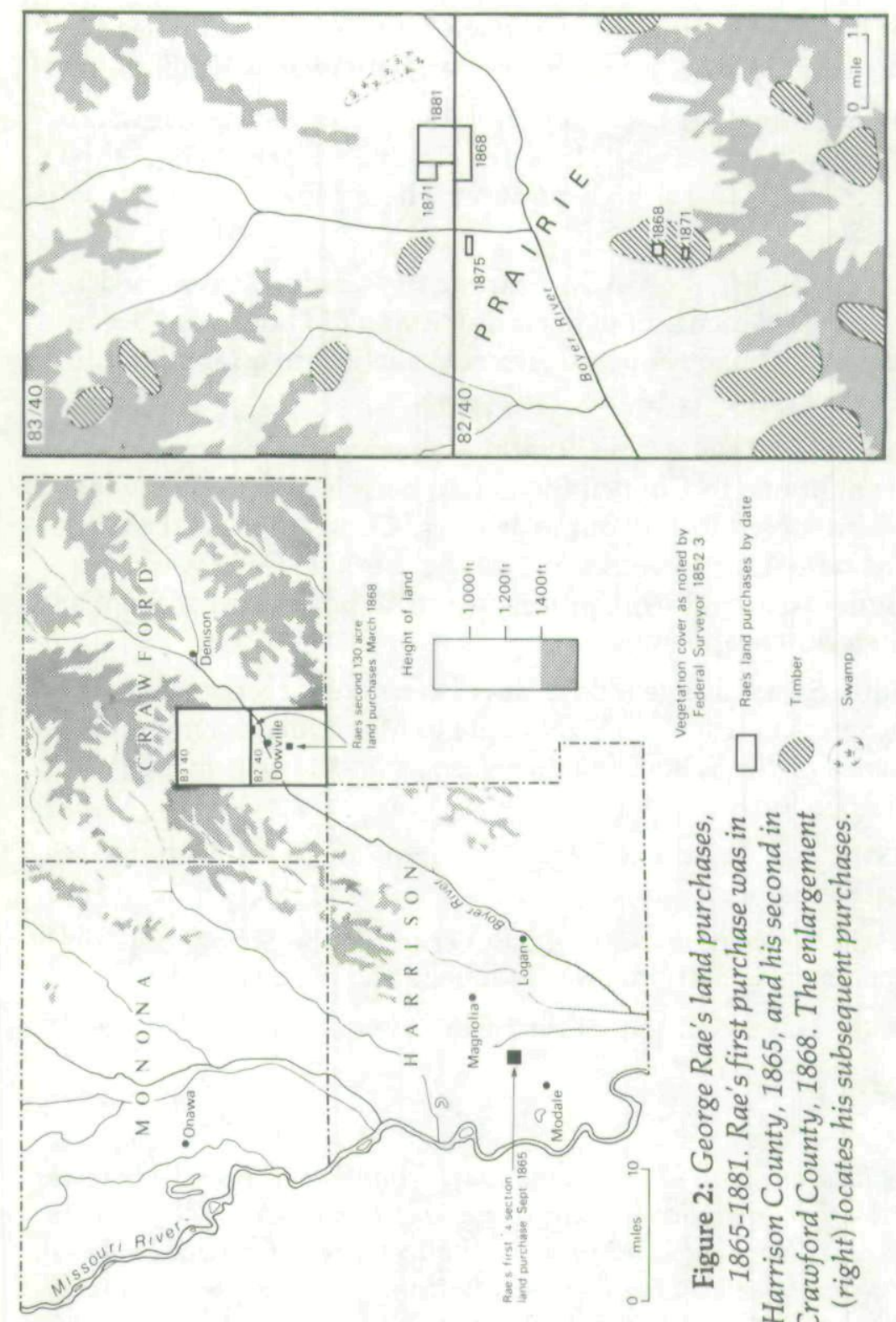

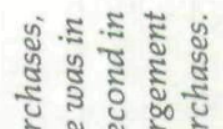
ปิ ปั

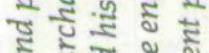

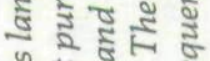
है ज赵 क०

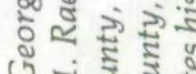

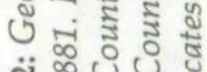
i $\infty u \cup$ 눈 논

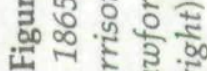
ग 
purchases in Crawford County were 120 acres of prairie on the northern edge of Township $82 / 40$ and a 10 acre block of woodland three miles south of his farm in a small timber grove. In focusing his farm on good prairieland and acquiring a timber supply at some distance he was doing as many other prairie farmers had done. ${ }^{9}$ Over the next thirteen years he added other parcels of land to his holding, including another small block of woodland, forty acres of railroad land close to his farm, and another quarter-section adjoining his existing holding.

Although no diary or other records exist to help explain why George Rae came to this part of the Boyer Valley to purchase a prairie farm, clearly he chose wisely in selecting land in Township 82/40. The federal government surveyor's 1852 report on the Township showed that this was one of the best-soiled acres of rolling prairie in the county with more timber groves scattered across the land than most. ${ }^{10}$ George Rae's extensive search for a farm had brought him to good prairieland. ${ }^{11}$

9See, for example, Leslie Hewes, "Some Features of Early Woodland and Prairie Settlement in a Central Iowa County," Annals of the Association of American Geographers 40 (1950): 40-57.

${ }^{10}$ Township report of D. Sales, Federal Government Surveyor, November 1852, General Land Office Fieldnotes, National Archives, Washington, D.C.

${ }^{11}$ That George Rae was satisfied with Crawford County as a place to farm is suggested by the fact that two years after his arrival a relative, possibly a younger brother, Thomas Rae, had also settled there from Fifeshire. (No details of this relative are available in the family papers.) Both names are recorded as farmers in 1875 in Union Township, Crawford County, in A. T. Andreas, Illustrated Historical Atlas of the State of Iowa, 1875 (Iowa City: State Historical Society), 538. 
Copyright of Annals of Iowa is the property of State of Iowa, by \& through the State Historical Society of Iowa and its content may not be copied or emailed to multiple sites or posted to a listserv without the copyright holder's express written permission. However, users may print, download, or email articles for individual use. 